\title{
Linkage analysis coupled with exome sequencing identified defects in gene ' $X$ ' causing premature ovarian insufficiency
}

\author{
Sulman Basit \\ From 2nd International Genomic Medical Conference (IGMC 2013) \\ Jeddah, Kingdom of Saudi Arabia. 24-27 November 2013
}

\section{Background}

Premature ovarian insufficiency (POI) is defined as a primary ovarian defect characterized by absent menarche (primary amenorrhea) or premature depletion of ovarian follicles before the age of 40 (secondary amenorrhea) with hypergonadotropism and hypoestrogenism. POI results in infertility and lifelong steroid deficiency, and is potentially associated with accelerated health risks such as cardiovascular and neurodegenerative disorders and osteoporosis.

\section{Materials and methods}

A large consanguineous Saudi family with three female affected with POI was investigated. All samples including 3 affected and 6 unaffected underwent whole genome SNP genotyping using Affymetric $250 \mathrm{~K}$ array. Linkage analysis was carried out using HomozygosityMapper and Allegro software. Candidate gene sequencing was performed using ABI3500 genetic analyzer. Whole exome was sequenced in three affected and one normal individual using life technologies Ion Proton sequencer.

\section{Results}

Linkage analysis mapped the disease phenotype to long arm of chromosome 20. Sequence data analysis of potential candidate genes failed to detect any pathogenic variant. Exome sequencing data analysis identified a deletion mutation in gene ' $\mathrm{X}$ ' on long arm of chromosome 20. This mutation is perfectly segregating with the disease phenotype in pedigree.

\section{Conclusions}

We identified a novel gene responsible for POI in Saudi Arabian family. Our findings extend the body of evidence that supports the importance of gene ' $\mathrm{X}$ ' in the development of ovary and ovarian reserves.

Published: 2 April 2014

\section{References}

1. Wu X, Wang B, Dong Z, Zhou S, Liu Z, Shi G, Cao Y, Xu Y: A NANOS3 mutation linked to protein degradation causes premature ovarian insufficiency. Cell Death Dis 2013, 4:e825.

2. Wang H, Sun M, Qin Y, Xia T, Ma J, Chen ZJ: Mutations in DMC1 are not responsible for premature ovarian failure in Chinese women. Reprod Biomed Online 2013, 26(2):175-8.

doi:10.1186/1471-2164-15-S2-P6

Cite this article as: Basit: Linkage analysis coupled with exome sequencing identified defects in gene ' $X$ ' causing premature ovarian insufficiency. BMC Genomics 2014 15(Suppl 2):P6.
Correspondence: sbasit.phd@gmail.com

Center for Genetics and Inherited Diseases, Taibah University Madinah AlMunawara, Kingdom of Saudi Arabia
Submit your next manuscript to BioMed Central and take full advantage of:

- Convenient online submission

- Thorough peer review

- No space constraints or color figure charges

- Immediate publication on acceptance

- Inclusion in PubMed, CAS, Scopus and Google Scholar

- Research which is freely available for redistribution 